\title{
POWER, CAPACITY, AND POLITICIZATION
}

In 1991, the EU adopted the urban waste water treatment directive. ${ }^{1}$ It obliges the member states to provide urban agglomerations with systems collecting and treating urban waste water until the end of 2000. In Spain, two-thirds of the treatment facilities did not comply with the requirements of the directive at the time of its enactment. To finance the building of new facilities and the upgrading of existing ones, the Spanish Water Treatment Plan of 1995 envisioned public investments of about $€ 10.8$ billion, which is five times more than Spain had invested in waste water treatment between 1985 and 1993. Why should member states comply with such costly EU laws? While Spain has made efforts to put adequate systems for collecting and treating waste water in place, Italy is facing financial penalties because after almost two decades, eighty of its urban agglomerations still fail to do so. ${ }^{2}$

In domestic politics, compliance is the rule rather than the exception. Students of public policy have been puzzled why "great expectations of Washington are dashed in Oakland" (Pressman and Wildavsky 1973). So-called top-down studies point to weak enforcement capacities of central authorities and insufficiently specified rules and procedures (e.g., Cerych and Sabatier 1986). The "bottom-up" literature contends that local actors and their preferences need to be accommodated in the policy process (Pressman and Wildavsky 1973; Lipsky 1980; Ingram and Schneider 1990). Both perspectives give rise to little optimism with regard to compliance with international and EU law. The international system and the EU lack a centralized enforcement authority, and member states are represented by their governments, giving local actors not much voice in the 
policy process. The default expectation of classical theories of IR, therefore, is noncompliance rather than compliance.

Students of IR have developed two approaches to explain why states may still comply with international and EU law. The literature has referred to them as enforcement and management (Chayes, Chayes, and Mitchell 1998; cf. Raustiala and Slaughter 2002; Simmons 1998; Tallberg 2002). The two schools are based on rationalist assumptions about state behavior and the constraining and enabling effects of international institutions. Social constructivists have added a third approach, which focuses on the role of international norms and norm-guided state behavior (Koh 1997; Hurd 1999; Checkel 2001).

The three approaches share a definition of compliance as state behavior that conforms to the requirements specified by an international norm or rule (Young 1979, 104; Chayes, Chayes, and Mitchell 1998, 39; cf. Raustiala and Slaughter 2002). States are the addressees of most international norms and rules and are formally responsible for compliance. However, they are not necessarily the main or exclusive targets (Chayes, Chayes, and Mitchell 1998, 52-53). Rules on climate change, for instance, target the production behavior of business, the driving behavior of car owners, and the energy consumption of private households. If the behavior of these non-state actors does not conform to international or EU law, states are in noncompliance because they fail to enforce the legal commitments they made. So is the Italian government, if its municipalities do not provide for the proper treatment of their waste water.

Enforcement, management, and legitimacy take compliance rather than noncompliance as the default preference of states. Enforcement expects states only to enter international agreements that correspond to their interests and shape them accordingly. This is why good news about compliance is not necessarily good news about international cooperation (Downs, Rocke, and Barsoom 1996). States are reluctant to make legal commitments that require costly domestic changes. If they do, noncompliance is likely, owing to the lack of strong enforcement at the international level, which depends on the willingness of states to exert material pressure. Such pressure can also arise, however, at the domestic level, where noncompliance may result in "audience costs" (Fearon 1994, 577) with domestic constituencies who support the international norm or rule (Dai 2007; Simmons 2009). "Electoral enforcement" (Simmons 2009, 369) can pull states toward compliance with costly international obligations.

Management assumes that noncompliance occurs because states lack the capacity rather than willingness to honor their international commitments (Chayes and Chayes 1993). This is less of an issue where international and EU law obliges states to refrain from certain actions, such as imposing tariffs or interfering with citizens' rights. Compliance with regulatory standards (e.g., for the 
treatment of waste water) in contrast, requires sufficient financial, technical, and human resources that states have to be able to mobilize to ensure effective implementation and enforcement (Weiss and Jacobsen 1998; Simmons 2009, chap. 8).

Legitimacy, finally, anticipates that states feel morally obliged to comply once they have internalized international norms and rules (Hurd 1999). States obey international and EU laws irrespective of their material costs because they accept them as legitimate and redefine their interests and identities accordingly (Franck 1990; Checkel 2001).

The three approaches specify different factors driving (non)compliant behavior. Enforcement focuses on material factors, which inform actors' preferences and shape their power to realize these preferences, thereby leading to (non)compliance. Social constructivist approaches stress the importance of the legitimacy of international institutions for shaping (non)compliance preferences of states. The management school assumes a general preference for compliance and sees insufficient state capacities as the major driving force for rule violations. These explanatory factors have informed many studies on compliance with international and European law. The growing body of empirical research, both quantitative and qualitative, has demonstrated that none of the three approaches alone is able to account for why states renege on their legal obligations (Tallberg 2002; Simmons 2009; Börzel et al. 2010). For enforcement, it is hard to explain why states comply with international norms and rules if these are costly. Management has to come to terms with states that refuse to abide with international and EU law despite having the capacity to comply. Legitimacy faces the challenge of noncompliance in states with a strong rule-of-law culture and public support for law beyond the nation state.

To address these puzzles, compliance studies started to work with more middle-range explanations focusing on particular issue areas, such as human rights (Simmons 2009; Risse, Ropp, and Sikkink 2013), trade (Goldstein, Rivers, and Tomz 2007; Kono 2007), security (Morrow 2007), or environment (Mitchell 2003b; DeSombre 2006). Students of compliance have explored specific causal mechanisms, including external enforcement pressures, domestic veto players, or transnational social mobilization. Quantitative methods have enabled the testing of an abundance of variables at a time. This has come with an "embarrassment of riches," though. The ambition of arriving at a coherent theoretical framework often has gotten lost in the attempt to cover a (too) broad range of possible explanatory factors.

This chapter develops a theoretical framework that combines power- and capacity-related factors with the concept of politicization in a theoretically consistent way. This will enable me to solve the three puzzles of this book: Why the member states that joined in 2004/2007 are less noncompliant than most 
of the older member states, why noncompliance has been declining since the mid-1990s, and why noncompliance is concentrated in policy sectors that seek to protect the rights of EU citizens.

\section{The PCP Model}

The PCP model conceptualizes the politics of noncompliance as a two-stage game played across two levels. To explain noncompliance, it is not sufficient to analyze the implementation and enforcement of international and EU law at the domestic level; we also need to consider the stage at which law is negotiated and adopted at the international or EU level. The PCP model systematically integrates the two stages of policy making by identifying factors that affect the costs of compliance and the ability of states to shape and take these costs at both the international and the domestic level.

Rooted in a rational institutionalist framework, the PCP model focuses on material costs of compliance and the power of states to shape these costs in EU decision making and to resist them in domestic implementation, as well as their capacity to cope with compliance costs at the domestic level. This reasoning follows the meta-theoretical willingness-opportunity framework (Cioffi-Revilla and Starr 1995; Starr 1978). The general claim is that every political action originates from the will or intent of states to act and their capability to do so. In other words, rule-consistent behavior of states requires both willingness and capacity.

The PCP model acknowledges that ideational factors matter. Norms have constitutive effects on actors' identities and preferences. They generate a sense of moral obligation to comply with their behavioral prescriptions. The international norm of law abidance linked to the principle of pacta sunt servanda sustains compliance with specific agreements (Chayes and Chayes 1993, 1995; Koh 1997). States also adapt their beliefs, standards for appropriate behavior, and even identities to international norms they have internalized (Checkel 2001). The EU is a community of law for which the supremacy of EU law is constitutive (Weiler 1999; Joerges 1996; Chalmers 1997). Membership in the EU has a constitutive effect on states and the way in which they exercise their sovereignty (Sbragia 1994; Laffan, O’Donnell, and Smith 2000; Risse 2010; Bickerton 2012). "The EC was created by law, ... its institutions are bound by law, and in turn the EC is a source of law" (Temple Lang, quoted in Laffan, O'Donnell, and Smith $2000,16)$. The general commitment of the member states to the rule of law may explain why the EU has no general compliance problem. Arguably, the default preference of member states is compliance. 
However, taking for granted that EU law is the law of the land does not mean that member states always comply with all EU legal acts all the time. Rather than explaining why member states comply with EU law, the PCP model seeks to understand why at times they do not, and why some do less than others do. It does so by making the constitutive effects of the EU's fundamental values defined in Article 2 TEU and the Charter of Fundamental Rights part of the context in which noncompliance may still occur.

\section{Preferences and Costs}

The PCP model starts from the assumption that actors are rational, goal oriented, and purposeful. Guided by their strategic rationality, actors operate instrumentally in order to maximize their interests or preferences over outcomes. The PCP model is state centered. Noncompliance is a "matter of state choice" (P. Haas 1998, 19). Preferences are crucial for shaping state choices of compliance or noncompliance (Thomson et al. 2006; Thomson, Torenvield, and Arregui 2007; König and Luetgert 2009; König and Luig 2014; König and Mäder 2014b). States' power and capacity affect whether and how they can pursue their choices. The PCP model assumes that states have basic interests, such as security, prosperity, or the respect for human rights and the rule of law. These basic interests are taken as given. So are states' policy preferences, such as opening markets or protecting the environment. Exogenizing basic interests and preferences over policy outcomes, the PCP model focuses on preferences over strategies. ${ }^{3}$ Compliance and noncompliance are strategies by which states seek to achieve their most preferred policy outcome deploying the power and capacity at their disposal.

Finally, actors create institutions in order to advance their preferences over outcomes. Institutions set the rules of the game. They embody rules and procedures, which regulate conflicts between states and help them to overcome collective-action problems (North 1990). Since the focus of the PCP model is on strategic preferences, it specifies how institutions create costs and benefits influencing states' strategic choices for (non)compliance.

Following the reasoning of enforcement approaches, states' preferences for (non)compliance are primarily shaped by the costs of compliance. States comply when international norms and rules coincide with their preferences over outcomes (Goldsmith and Posner 2005). Conversely, they will violate even technical and narrow legal acts if these require costly institutional or behavioral changes (Downs, Rocke, and Barsoom 1996). This is particularly the case if states face the risk of other states defecting. This risk makes them inclined to shirk the costs, too. The way to effectively prevent noncompliance is by increasing the costs of noncompliance (Martin 1992; Dorn and Fulton 1997). Establishing external 
institutionalized monitoring and sanctioning mechanisms can alter the strategic cost-benefit calculations of states (Axelrod 1984; Oye 1986). The likelihood of being detected and punished raises the anticipated costs of noncompliance in form of economic sanctions, retaliation, financial penalties, withdrawal of membership privileges, or expulsion (Chayes and Chayes 1991,314-318; Martin 1992; Fearon 1998). Such costs may finally lead to a change of strategic behavior toward compliance.

Even highly legalized enforcement mechanisms, however, ultimately rely on the willingness of states to impose sanctions authorized by the dispute settlement panels of the World Trade Organization, the United Nations Security Council, or under the Article 7 procedure of the EU (Hafner-Burton 2005; Lebovic and Voeten 2009). Enforcement acknowledges the importance of power for state-tostate coercion to enforce costly norms and rules. States, however, may not only use their power to deter or sanction the defection of others. Power allows them to reduce compliance costs and makes them less susceptible to sanctions in the first place.

\section{Power}

Power is closely related to the ability of states to shape legal acts according to their preferences over outcomes (Giuliani 2003; Moravcsik 1997a; Fearon 1998; Keohane and Nye 1977; Thomson et al. 2006). The extent to which a state has managed to realize its preferences in the decision-making process shapes the adjustment costs, which a state has to invest in order to comply (cf. Börzel 2002a, 2003a; Giuliani 2003). States that are more powerful should be better compliers, since they are able to reduce the costs of compliance by shaping international and EU law according to their policy preferences.

If adjustment costs matter, a state's overall cost sensitivity crucially affects its strategic preference for noncompliance. Following the argument of Keohane and Nye (1977) on power and interdependence, states can be regarded as being more sensitive to sanctioning costs imposed by others if they have less power and are more dependent than other states on future goodwill and cooperation. Powerful states can afford to be more resistant to enforcement pressures, since they have more alternatives for cooperation and can more easily afford reputation or material damages. In other words, power affects the cost sensitivity of a state. Less powerful states should be more susceptible to sanctioning costs and therefore be less likely to violate international or EU law (Martin 1992). Conversely, powerful states can be recalcitrant and resist enforcement pressures (Börzel et al. 2010).

The power of a state does not only allow it to shirk compliance costs or avoid them in the first place, by shaping international decisions according to its 
preference. State power can also deter the enforcement authority-the institution that monitors compliance and authorizes sanctions against free riders and norm violators. Assuming a principal-agent relation, the enforcement authority (agent) ultimately depends on the states (principals) since the latter can always renounce the power of the former (Horne and Cutlip 2002, 301; Garrett, Kelemen, and Schulz 1998; Tallberg 2000a; Fjelstul and Carrubba 2018; Larsson and Naurin 2016). Powerful states should be less compliant, since enforcement authorities, as well as other states, are more reluctant to inflict noncompliance costs on them.

In sum, power matters for compliance because it affects compliance costs, although in conflicting ways. "While the strong do what they can ... the weak suffer what they must," as classical realism would have it (Thucydides 2009, 5.89-[1]). Strong states can use their power either to reduce compliance costs, to resist them, or to deter enforcement authorities. If they choose resistance or deterrence, states are more likely to be noncompliant. If, however, they use their power to shape international and EU laws, they should be better compliers than states that are less powerful.

Power is not the only determinant of costs. Management approaches stress the importance of states having the necessary capacities to implement and enforce international and EU law. States can use their capacities (as well as their power) at the decision-making stage to reduce compliance costs by shaping legal obligations according to their interests and policy preferences. Capable shapers are also capable takers.

\section{Capacity}

States generally have been willing and able to abide by their international obligations. The PCP model draws on the three preconditions that management approaches have identified for the ability of states to comply: sufficient state capacities, clear definitions of legal obligations, and adequate timetables for achieving compliance (Chayes and Chayes 1993; Chayes, Chayes, and Mitchell 1998; Young 1992; P. Haas 1993, 1998; Jacobsen and Weiss Brown 1995).

A state's ability to act in accordance with its international legal requirements is a function of its legal authority and financial, military, and human resources (Przeworski 1990; Haas 1998; Simmons 1998). States need sufficient and adequately qualified personnel to effectively implement international and EU law. They must also have the legal knowledge of the precise behavioral requirements that result from the law and the technical expertise for the practical application of the law and the monitoring of compliance (cf. Chayes and Chayes 1993). Financial resources do not only allow for the acquisition of additional personnel, 
expertise, and technical equipment. They can also help pay off the delegation of implementation tasks to third actors (outsourcing) and compensate potential losers of a policy (cf. Börzel 2003a, 30-34; cf. Simmons 1998; Zürn 1997).

Yet even if a state has legal, financial, military, and human resources, its administration may still have difficulties in pooling and coordinating them, particularly if the required resources are dispersed among various public agencies (e.g., ministries) and levels of government. Compliance depends on the efficiency of a state's bureaucracy in using available resources to ensure rule-consistent behavior (Simon 1962; cf. Bouckaert, Peters, and Verhoest 2010; Rauch and Evans 2000; Fukuyama 2015). When centralization is too costly or institutionally not an option, public administrations have to rely on coordination procedures. Moreover, the efficiency of a bureaucracy hinges on its professionalism and the extent to which its organization is rational (Gajduschek 2003). Clientelism and other forms of corruption systematically undermine bureaucratic efficiency since public resources are (ab)used for rent seeking rather than delivering (international) policy outcomes (Rothstein and Teorell 2008; Rothstein 2011; Mungiu-Pippidi 2015). The less efficient the bureaucracy of a state is, the more likely noncompliance becomes.

Finally, states require the autonomy to make decisions and reach goals independently of societal interests (Nordlinger 1981, 1; cf. Katzenstein 1978; Evans 1995; Evans, Rueschemeyer, and Skocpol 1985). "Involuntary defection" (Putnam 1988) often results from powerful domestic veto players that block the ratification and implementation of international agreements because of the costs they, or their constituents, have to bear (Alesina and Rosenthal 1995; Tsebelis 2002). By definition, veto players have the ability to prevent changes of the status quo (Tsebelis 2002). States with a high number of domestic veto players are more likely to violate international and EU law because of their reduced capacity to make the changes to the status quo that are necessary for their compliance with costly rules.

The capacity to comply is primarily a function of a state's resources, its bureaucratic efficiency, and its domestic autonomy. Management approaches also identify factors that are not related to states but affect their capacity to comply. International and EU laws differ in how demanding they are on state capacities. States have greater difficulties in complying with imprecise and complex norms and rules since they are unclear about what rule-consistent behavior requires and may arrive at diverging interpretations of what they are expected to do (Chayes and Chayes 1993; Chayes, Chayes, and Mitchell 1998). Complex rules may not only give rise to diverging interpretations; they also involve a bigger workload, requiring more legal and administrative measures to enact new and amend existing national legislation. Precise and simple international norms and rules have 
better chances to be complied with (Kahler 2000; Abbott et al. 2000; Tallberg 2002; Helfer and Slaughter 1997).

Compliance with international and EU law, finally, requires states to introduce legal, administrative, and social changes that take time. Strict deadlines may be a disciplining factor for states to step up their compliance efforts. If deadlines are too tight, however, states may not have sufficient time to clarify their legal obligations, mobilize resources, and introduce the required institutional and behavioral changes (Chayes and Chayes 1993, 195-197). The less time international and EU laws leave states to comply, the more likely those laws are to be violated.

In sum, states that want to comply with international and EU law need the necessary resources, efficiency, and autonomy to do so. Moreover, some laws require more state capacity than others. While management approaches focus on the capacity of states to take international and EU law, resources and efficiency should also help states shape it according to their preferences. Domestic autonomy, in contrast, has an opposed effect on shaping and taking.

\section{Politicization}

International norms often cannot rely on international enforcement mechanisms that substantially raise noncompliance costs. Research has therefore increasingly focused on social mobilization at the domestic level as an alternative way to raise the costs of noncompliance. Domestic actors, in transnational alliances with NGOs, exploit international norms and institutions providing information on norm violations to generate pressure for compliance on state actors (Rogowski 1989; Brysk 1993, Keck and Sikkink 1998; Risse, Ropp, and Sikkink 1999). International enforcement activities empower them to punish state governments for noncompliance (Börzel 2000a; Dai 2007; Simmons 2009). Such "audience costs" (Fearon 1994, 577) tend to be higher in democratic states, which are the focus of this study. Governments are office seeking and vulnerable to electoral costs imposed by larger numbers of citizens who support international and EU law, and NGOs form powerful transnational alliances (Gaubatz 1996; Slaughter 1995). At the same time, "electoral enforcement" (Simmons 2009, 369) is often undermined by anti-compliance constituencies that mobilize against the costs of changing the status quo.

The PCP model focuses on domestic mobilization against, rather than in favor of, compliance, since its general assumption is that states comply with EU law. The challenge is to explain why states do not comply, which should be more likely when they run into powerful domestic resistance. The compliance literature tends to focus on advocacy coalitions, NGOs, interest groups, or companies pulling states toward compliance (e.g., Keck and Sikkink 1998; Börzel 2003a; 
Slaughter 2004; Dai 2007; Simmons 2009). Yet transnational and domestic actors not only monitor compliance, pressure international institutions to take action against state violations, or mobilize and litigate against states that are reluctant to abide with international law. They can also put pressure on states to shirk their legal obligations.

Domestic mobilization against compliance is not only a function of the costs incurred on domestic actors (Siegel 2011). To mobilize, these domestic actors have to be aware of and care about the costs. Two-level-game scholars have convincingly argued that the main reason for states to pool and delegate decision-making power in international institutions is that it allows them to adopt policies they would "never get accepted at home" (Putnam 1988, 440; cf. Evans 1993). "Cutting slack" (Putnam 1988) or trading national sovereignty for problem-solving capacity has helped to "rescue the nation-state" (Milward 1992) and "strengthens the state" vis-à-vis particularistic interest in their societies (Moravcsik 1994, 1997b; Wolf 2000). State governments use international negotiations to achieve policy outcomes that their constituencies might otherwise reject. Circumventing domestic opposition works because citizens tend to be less informed about international and EU law. Since international law falls into the realm of foreign policy, which is the government's prerogative, citizens often do not hold strong opinions either.

With the expansion of their political authority after the end of the Cold War, however, international institutions have become increasingly visible and politically contested (Zürn 2012; Zürn, Binder, and Ecker-Ehrhardt 2012). Rather than being indifferent, citizens have been taking a stance on costly international and EU policies, the Transatlantic Trade and Investment Partnership being a prominent example. The literature refers to the visibility and political contestation of international institutions as politicization. Politicization has three dimensions (see, e.g., De Wilde, Leupold, and Schmidtke 2016; Hutter, Grande, and Kriesi 2016, 7-12; Risse 2015a):

- Increasing issue salience of international and EU laws in the various public domains

- Increasing levels of polarization pertaining to international and EU law (i.e., citizens strongly oppose or support EU laws rather than being neutral, ambivalent, or indifferent)

- Increasing mobilization and expansion of actors in the various public domains (i.e., domestic actors are willing to act politically on their polarized views, going to the polls or protesting in the streets)

Research has primarily dealt with politicization as an impediment for international and regional governance (Zürn 2018; Hooghe, Lenz, and Marks 2019). 
It does not only affect the making of international and EU law. Politicization also undermines the chances of compliance by mobilizing domestic opposition, reducing the autonomy of states to comply. This is particularly likely in states where citizens are skeptical of global or regional governance (Norris 2000; Pichler 2012; Jung 2008) and where public support for membership in international institutions and the EU is low (Börzel 2016, 2018). Euroscepticism should increase the propensity of domestic audiences and veto players to pull states away from rather than toward compliance with EU law. Yet politicization does not necessarily have to increase the odds of noncompliance. Similar to domestic veto players, politicization constrains the number of international outcomes that a state government can get ratified at the domestic level. This domestic weakness can turn into international strength (Schelling 1960). The degree of anticipated opposition in a state determines the size of the domestic win-set- that is, the number of outcomes that are likely to be ratified at the domestic level. The more constrained the autonomy of the government, the smaller the size of its domestic win-set tends to be in international negotiations. The smaller its domestic win-set is, the greater a government's ability to shape policy outcomes at the international level because it can "tie its hands" to the preferences of its main constituencies (Putnam 1988; Evans, Jacobson, and Putnam 1993; Bailer and Schneider 2006). The greater the saliency a government attaches to the legislative output, the greater its shaping power (Schneider, Finke, and Bailer 2010). Governments of states where support for international and EU law is low can more credibly claim that their hands are tied by their domestic publics, since those publics are likely to mobilize against compliance with costly legislative outputs (Hug and König 2002; Finke and König 2009).

Somewhat paradoxically, the very reason why states pool and delegate authority at the regional and international level may empower their governments to obtain international policy outcomes that satisfy the domestic constituencies whose opposition they seek to circumvent. A state with autonomy vis-à-vis society is more prone to noncompliance because its government can isolate itself from domestic audience costs (see above). The government also has reduced power to achieve less costly policy outcomes at the international level.

Summing up, the PCP model takes the costs of compliance as the crucial determinant of states' preferences for or against complying with international and EU law. In a two-level game approach, power, capacity, and politicization condition these costs. They do so in partly conflicting ways, though, depending on the stage of the compliance game. The remainder of this chapter spells out how the compliance game plays out across the two levels and two stages. This will provide the model specification necessary to account for variation in noncompliance across states as well as time and policy areas. 


\section{The Politics of Noncompliance: A Two-Stage Game across Two Levels}

Most theories approach European integration and EU policy making as a multilevel process (for an overview see Wiener, Börzel, and Risse 2019). Where they differ is how the domestic and the EU level interlink. Liberal intergovernmentalism emphasizes the gatekeeping role of national governments, which control access to decision making at the EU level (Moravcsik 1993, 1998). While domestic actors are important in forming the policy preferences of member states, they do not have an independent role in shaping policy outcomes at the EU level. Nor do supranational actors. The European Commission, the ECJ, or the European Central Bank (ECB) help member state governments arrive at policy outcomes that serve their national interests. Neofunctionalism and its variants contend that domestic interests (e.g., business associations, trade unions, and subnational authorities) demand further integration to promote their economic or political preferences. They form transnational alliances with like-minded groups from other states and ally with supranational actors, thereby bypassing their state governments, since the latter are reluctant to pool and delegate political authority at the regional level. The European Commission and the ECJ provide domestic actors with direct access to the EU policy arena out of institutional self-interest in increasing the power of supranational institutions over the member states (E. Haas 1958; Sandholtz and Stone Sweet 1998; Hooghe and Marks 2001).

Without denying the relevance of supra- and subnational actors, the PCP model adopts the liberal intergovernmentalist conceptualization of EU policy making as a two-level game. The focus, however, is not on domestic preference formation but on the "reciprocal relationship" (Andersen and Liefferink 1997) between politics at the domestic and the EU level, with the national governments functioning as the core mediators between the two. This is not to say that supranational actors do not matter for compliance. As enforcement authorities, the Commission and the ECJ can increase the costs of noncompliance. Moreover, through its case law, the ECJ can directly shape EU laws increasing the costs of compliance (Schmidt and Kelemen 2014; S. Schmidt 2018).

I argue that it is not sufficient to study compliance at the stage at which member states "take" EU laws by implementing and enforcing them (policy-taking stage). We also need to look at how member states shape EU laws in their negotiation and adoption (policy-shaping stage) because this is the stage that defines the size of compliance costs in the first place (Börzel 2002a, 2003c; Dai 2005, 2007). ${ }^{4}$ At the domestic level, actors pressure their national governments to shape EU laws in a way that favors their interests. At the EU level, member state governments push for EU laws that satisfy the interests of their constituencies, while 
minimizing their adverse consequences at the domestic level (Putnam 1988, 434; cf. H. Wallace 1971; Héritier, Knill, and Mingers 1996; Bomberg and Peterson 2000; Börzel 2002a; Dyson and Goetz 2004). Two-level game approaches provide a link between the shaping (decision-making) and the taking (implementation) stages of the EU policy process. While research on the shaping and taking of EU policies shows significant overlap, few attempts have been made to draw the two strands of literature together (but see Keulen 2006; Börzel 2002a; Börzel and Hofmann 2010; Siegel 2011; Sprungk 2011; Knoll 2016).

Member states share a general incentive to shape EU laws according to their domestic policy arrangements. Because of their political, economic, and social diversity, they have, however, diverging policy preferences and differ significantly with regard to their ability to both shape EU laws in order to reduce compliance costs, and to take EU laws coping with compliance costs. The ability to shape and take EU laws is heavily influenced by the three principal components of the PCP model-power, capacity, and politicization.

\section{The Shaping Game: Reducing Compliance Costs}

\section{THE EU LEVEL}

The literature on state power in EU decision making focuses on the political clout (Wright 1999) or institutional weight (Hosli and Soetendorp 2001) of the member states in EU decision-making bodies. Large member states have significant voting power under qualified majority voting in the Council of the EU. Because of QMV, they cannot be ignored by others in EU decision making (cf. Thomson et al. 2006). The institutional power of the largest member states reflects the size of their populations and their economies. ${ }^{5}$ The EU's "big four," Germany, France, the UK, and Italy, are able to block the adoption of EU laws in the Council. As the largest economies in the EU (measured by GDP), they pay more than 60 percent of the EU budget. After the UK left in 2020, Germany, France, and Italy have gained even more weight. ${ }^{6}$

Shaping EU policy outcomes does not merely depend on votes or budget contributions, though. Unable to push national positions through the EU negotiation process against the opposition of other member states with diverging policy preferences, small member states often rely on their capacity to efficiently coordinate and articulate their policy preferences in the EU policy-making process (Kassim et al. 2000; Zeff and Pirro 2001; Bulmer and Lequesne 2005). Denmark, Sweden, or the Netherlands, where EU-related policy-making competencies are concentrated in the central government, are able to formulate and represent a coherent bargaining position and stand a better chance to be heard than countries like Greece or Italy, where competencies are fragmented and as a result the 
government does not always speak with one voice (Kassim et al. 2000; cf. Kronsell 2002; Panke 2010a). Offering expertise and information to the European Commission in the drafting of policy proposals is also an effective way of injecting national preferences into the European policy process. So is the secondment of national bureaucrats to Brussels for up to three years. The Commission often asks member states to send experts with specific knowledge to help prepare European directives (Andersen and Liefferink 1997). Being present in the various networks that prepare and accompany the EU negotiation process demands considerable staff, expertise, and information, as well as a significant amount of coordination, which the member states do not have equally available. The efficient use of their resources allows smaller states to "punch above their weight" (Panke 2010a).

\section{THE DOMESTIC LEVEL}

For two-level game approaches, domestic veto players are an important domestic source of state influence in international or EU negotiations. Because they have the power to block the ratification of international and EU law, domestic veto players give governments additional leverage in negotiating outcomes that are closer to their policy preferences. This is particularly relevant for EU directives, which need to be transposed into national law and often require the involvement of national parliaments. Moreover, industry may mobilize against investments in new technologies or against changes in their production processes necessary to meet international or EU environmental, social, or safety standards. Trade unions may fear the loss of jobs. Environmental, social-rights, and consumer groups may be concerned about a lowering of existing standards or demand even stricter standards than the ones prescribed by international or EU law. The more veto players a government is likely to face at home, the greater its advantage in shaping policy outcomes that entail lower compliance costs.

In the literature, the power of domestic veto players is largely determined by domestic institutions. EU member states are liberal democracies, in which power is divided and shared, albeit to different degrees, between the three government branches (executive, legislature, judiciary) as well as between different levels of government (national, regional, local). In states with corporatist structures, veto players also arise from institutionalized forms of cooperation between state and society. Rather than the number of veto players or institutional veto points (Immergut 1990), however, the PCP model focuses on politicization as the domestic constraint that empowers member state governments to shape EU law. On the one hand, similar to domestic veto players, politicization increases the chances of noncompliance with costly EU laws. If business, interest groups, or citizens are aware and care, they are more likely to mobilize against compliance costs, threatening to withdraw their political support for the government. 
On the other hand, member state governments that can credibly claim that costly EU laws will likely become politicized have an advantage in shaping EU policy outcomes. They can tie their hands against compromising in EU negotiations by arguing that costly EU laws stand little chance of compliance at home. Claims about domestic politicization are more credible when domestic support for the EU is low. Eurosceptic publics are more likely to be aware of and care about compliance costs. Politicization can thereby not only substitute for domestic veto players. It can also render domestic veto players more likely to invoke their power to block compliance with costly EU laws. Conversely, a low likelihood of domestic politicization owing to strong public support for the EU undermines hand-tying strategies of member state governments because they cannot credibly threaten that veto players will actually use their power to prevent compliance with costly EU laws. Instead of tying their hands, consistent public support for the EU allows governments to expand their domestic win-set. They can accommodate EU policy outcomes that their constituencies might otherwise reject by presenting them as take-it-or-leave-it decisions or by blaming them on the need to compromise with other member states, the Commission, and the European Parliament in order to reach an agreement at all (the very common adage "Brussels made us do it"). Conversely to tying hands, cutting slack results in higher compliance costs, which, however, are less likely to be politicized at the domestic level but still require capacity to cope with.

So far, the shaping game focuses on the ability of member states to lower compliance costs. However, power, capacity, and politicization of the member states are country-related variables. They cannot explain variation across time and across policy sectors. The PCP model therefore introduces EU institutions that mitigate the ability of member states to shape EU law. They have changed over time and differ according to the policy sector.

\section{EU INSTITUTIONS}

EU rules by which EU law is adopted define the degree to which member state governments can shape compliance costs. Since the early 1990s, the EU more than doubled in member states; it also expanded QMV in the Council and the codecision powers of the European Parliament (EP). This subsequent widening and deepening of European integration increased the heterogeneity of member state preferences while diminishing the veto power of individual member states. Not only do member states have to compromise in the Council to reach agreement. The EP has the power to amend decisions of the Council that move policy outcomes further away from its own preferred policy outcome. The relative voting power of member states has not substantially changed. Throughout the various treaty changes, France, Germany, Italy, and the UK have remained able to resist 
compliance costs. However, if member state governments are outvoted in the Council of Ministers, or if they have to compromise with the European Parliament under the co-decision procedure, compliance costs are likely to be higher because policy outcomes are moved further way from their policy preferences (Moravcsik and Vachudova 2003; König and Bräuninger 2004; Kaeding 2006; Thomson, Torenvield, and Arregui 2007; Steunenberg and Kaeding 2009; Dimitrova and Toshkov 2009; Steunenberg and Rhinard 2010; Plechanovová 2011). Finally, the ECJ can increase compliance costs by adopting case law in response to domestic actors that seek to expand the scope of EU law (see chapter 1; Schmidt and Kelemen 2014; S. Schmidt 2018).

The nature of EU law adopted at the shaping stage has major implications for the costs member states have to take. Flexibility reduces compliance costs by providing member states with more time to take them. EU law grants transition periods and (temporary) exemptions. Such differentiated integration (Holzinger and Schimmelfennig 2012; Leuffen, Schimmelfennig, and Rittberger 2013) pays tribute to differences in capacity and competitiveness among the member states. The most prominent example is the euro. Member states are obliged to adopt the EU's single currency-but only if they have sufficient capacities to comply with the Maastricht convergence criteria. Likewise, participation in the Schengen Agreement, which abolishes any kind of border control among the member states, is conditional on effective external border control systems. This "preferential treatment of the weak" (Schimmelfennig 2014a) supports the integration of new members, particularly if they are newly democratizing and poor (Sedelmeier 2005, 9).

Flexibility also varies between the two main types of legal acts that member states have to comply with. Directives and regulations are adopted by the same decision-making procedures. Directives, however, leave member states more flexibility because they should only "specify the results to be achieved" but "leave to national authorities the choice of form and methods," while a regulation "shall be binding in its entirety and directly applicable in all Member States" (Article 249 TEU).

At the same time, however, directives are framework legislation, which increases their complexity. They define broad goals and have to be explicitly incorporated into national law. Unlike regulations, which are directly applicable and automatically override national laws, directives require transposition into national law involving a multitude of actors (civil servants, parliaments) to adjust domestic structures. Besides coping with the additional workload that directives entail, these actors can block or at least delay compliance.

Costs also arise from the novelty of EU law. New laws require comprehensive changes in the domestic structures of the member states in order to reach 
compliance with EU law. These changes should be smaller, and thus less costly, if EU law amends already existing legislation rather than issuing new regulations. Updating technical standards or tightening environmental standards requires fewer changes than adopting new legislation and setting up new administrative procedures.

Finally, delegation reduces the risk of compliance costs becoming politicized. Depending on the legislative procedure, directives are adopted by either the Council as the sole legislator (special legislative procedure) or the Council and the European Parliament as co-legislators (ordinary legislative procedure). A third type of directive can be adopted by the Commission as "tertiary legislation" (Junge, König, and Luig 2015). Tertiary legislation can take the form of delegated or implementing acts. These acts involve the further elaboration or updating of standards and technical issues of an existing legislative act. Commission directives are not only less costly to comply with for public administration. They are also less likely to become politicized because they are more technical in nature and are (therefore) adopted by the Commission rather than the Council and the Parliament (cf. Héritier et al. 2013). The chances of politicization are further reduced by the lack of parliamentary involvement. Parliamentary debates raise the salience of EU policies (Rauh and De Wilde 2017; S. Schmidt 2018), also at the EU level when the European Parliament debates legislative proposals and introduces amendments (Häge 2010). Highly salient EU laws mobilize political opposition by and within national parliaments (Dimitrakopoulos 2001).

Variables related to characteristics of EU laws are time sensitive but do not necessarily differ between policy sectors. In order to explain sectoral variation, the PCP model needs to incorporate factors that are sector or policy specific. Drawing on the seminal work of Theodore Lowi (1972), public policy analysis distinguishes between different policy types and regulatory logics. (Re)distributive policy (e.g., agriculture, or regional policy) requires direct public expenditures; the member states need to deal with these costs at the stage of decision making. Once states have agreed how much money to allocate to funding regional development projects, costs are no longer an issue because those who will not benefit from them or have to pay for the costs are not involved in the implementation. For regulatory policy it is the opposite; the costs of policy formulation and decision making for environment or health and food safety regulations are relatively low at the EU level but often significant—in material and political terms-when it comes to the implementation of EU laws at the domestic level. In other words, regulatory policy produces higher compliance costs than nonregulatory policy (Majone 1993, 1996).

Costs are particularly high when regulatory policy aims at correcting market failures. Compliance with regulatory policy designed to open national markets 
may incur costs for some domestic actors, such as companies that are not internationally competitive. However, such market-making policy does not require member states to take action or develop and police the application of new legislation. In order to remove obstacles to market integration, member states mostly have to abstain from interfering with the free flow of market forces by not levying import tariffs and export fees and not controlling borders. Market-correcting policy, in contrast, explicitly requires states to actively interfere in market and society (Scharpf 1999; H. Wallace 2005). The implementation of common environmental, health, or labor standards is more costly than the control of mergers, price collusions, or state subsidies. Member states have to enact new legislation, invest additional administrative resources, and strengthen administrative coordination to enforce it. The costs of market-correcting policy are also more likely to become politicized. The "regulatory competition" (Héritier 1996) among the member states makes any compromise at the EU level prone to domestic opposition, by, for instance, business sectors that face higher production costs because they have to invest in new abatement technology or pay higher wages.

In sum, EU law is often costly at least for some member states. How high the costs are and who ultimately has to bear them depend on the degree to which member states are able to shape EU law according to their policy preferences. This is a matter of power and capacity, as well as the politicization that states are likely to face when taking EU law.

Costly EU law does not automatically result in noncompliance, though. The PCP model assumes that the default strategic preference of states still is compliance. Member states generally accept the supremacy of EU law and have a common interest in making the EU work. Whether member states violate costly EU laws ultimately depends on how they cope with the compliance costs. The PCP model argues that power, capacity, and politicization are as important in the taking game as they are in the shaping game.

\section{The Taking Game: Coping with Compliance Costs}

Once an EU law is adopted, member states have to implement it. For directives, this entails the transposition into national law. Regulations, in contrast, are directly applicable. Member states have to practically apply and enforce both types of EU law. They can cope with the ensuing compliance costs either by resisting the necessary changes at the EU level or by bearing the costs at the domestic level.

\section{THE EU LEVEL}

Power should not only allow member states to shape EU policy outcomes according to their policy preferences. Power also matters for the extent to which they 
are able to resist compliance costs by simply noncomplying. Institutional mechanisms for monitoring compliance and coordinating sanctions are intended to mitigate the risks of such free-riding behavior (Keohane 1984; Boyle 1991). Institutions increase the likelihood of noncompliance being detected and punished, thereby raising the (anticipated) costs of noncompliance. As the guardian of the treaties, the European Commission has ample monitoring and sanctioning powers. Besides carrying out its own investigations, it can rely on information provided by business, interest groups, and citizens. Infringement proceedings allow the European Commission to prosecute offenders. Legal action may not only result in financial penalties. The loss of credibility as a reliable cooperation partner may also lower the political leverage of governments in future negotiations (Morrow 1999).

Powerful states are less vulnerable to sanctioning costs. Financial penalties imposed by the ECJ are calculated on the basis of a member state's GDP. Still, rich member states are better able to pay than poor member states, which are heavily dependent on EU funding and thus the financial and political support of other member states. Large member states can also more readily afford to lose reputation since the European Commission and smaller member states are not in the position to ignore them; their consent is needed for the adoption of EU law.

Rather than resisting noncompliance despite additional sanctioning costs, states could also use their power to deter international institutions or other states from enforcing compliance in the first place. The first member state to violate the Maastricht convergence criteria was Germany. Unlike Portugal, Greece, or Ireland, Europe's largest economy was never officially reprimanded under the Stability and Growth Pact, which the euro-group countries adopted, pressured by Germany, to enforce fiscal discipline (Heipertz and Verdun 2004). The European Commission could be more reluctant to enforce compliance against big and rich member states because of their political and economic power.

\section{THE DOMESTIC LEVEL}

Member states may not only be unable to dodge compliance costs at the EU level; they may also lack the capacity to cope with them at the domestic level. Effectively taking EU laws by paying off the costs they incur requires resources as does shaping EU laws to reduce the costs in the first place. States substantially differ in their resource endowment. Industrial countries, in principle, should have the resources necessary to comply with their obligations under international and EU law. The challenge they face is to mobilize and pool available resources or coordinate those parts of the administration whose legal competence or technical expertise is required to introduce legal and administrative changes and apply the new policy. 
Next to resources and efficiency, state governments need to have the autonomy to implement and enforce their legal obligations. In the shaping game, domestic veto players should increase the ability of governments to reduce costs, decreasing the chances of noncompliance. Once an EU law is passed, however, these veto players have the opposite effect, making noncompliance more likely because they have the power to block the changes necessary for compliance (Tallberg 2002; Börzel et al. 2010; Zhelyazkova, Kaya, and Schrama 2016). Yet simply counting the number of domestic actors that are able to veto compliance to shirk costs ignores that these actors have to be aware and care about the costs. The question then is what makes international agreements publicly visible and politically relevant to domestic actors, particularly in the EU, which has for the longest time evolved through "integration by stealth" (Majone 2005).

Domestic politicization is more likely in member states where public support for the EU is low. Moreover, research has shown that EU laws are particularly likely to become politicized when parliaments get involved. Parliamentary debates raise the salience of EU laws (Rauh and De Wilde 2017). This is also the case at the EU level when the European Parliament debates legislative proposals and introduces amendments (Häge 2010). Highly salient EU laws mobilize political opposition by and within national parliaments (Dimitrakopoulos 2001). As important veto players, parliaments are a direct source of noncompliance. At the same time, parliamentary involvement has a more indirect effect by making the politicization of compliance costs more likely so that national governments will prefer to shirk them.

\section{EU INSTITUTIONS}

EU institutions do not only influence the ability of member states to shape compliance costs, introducing temporal and sectoral variation. They also affect the taking of these costs by rendering noncompliance more costly or by helping member states to cope with the costs.

Institutional monitoring and sanctioning mechanisms shall "raise the costs of violation or . . lower its profit" (Audretsch 1986, 410). The more monitoring information the European Commission obtains through complaints and petitions from business, interest groups, and citizens, or its own investigations, the greater the risk for member states to get caught in noncompliance. The EU has developed new monitoring tools, such as SOLVIT and EU Pilot, which are intended to assist citizens and business complaining about the improper application of directives (Hobolth and Sindbjerg Martinsen 2013; Koops 2011). In 1992, the Maastricht Treaty introduced the possibility for the ECJ to impose financial penalties to sanction persistent noncompliance (see chapters 1 and 4). The Internal Market Scoreboard, which was established in 1997, is designed to increase 
reputational costs by naming and shaming member states. The worst performers are put on the spot, not only among fellow governments but also in the public media (Tallberg 2002, 63).

Next to strengthening its enforcement capacity, the EU has developed different instruments to manage compliance by helping member states to take EU laws. To weed out cases caused by legal uncertainty and misunderstandings, such as those due to poor drafting, the Commission installed a series of contracting mechanisms. These include informal information and consultation during the preliminary stages of the infringement proceedings, and the bilateral meetings the legal services of the Directorate-Generals hold with their colleagues in the corresponding national ministries of the member states. The Commission also issues recommendations, resolutions, guidelines, action plans, and other forms of soft law to provide the member states with guidelines on how to interpret EU directives and regulations (Scholten 2017; Maggetti and Gilardi 2014; Falkner et al. 2005). To help build the necessary capacity for member states to take EU law, the EU offers financial and technical assistance under various EU funds and funding programs, such as the European Regional and Development Fund or the Cohesion Fund. It also orchestrates transgovernmental networks that bring together national administrators in charge of implementing EU law to foster the development of a common understanding of what compliance entails and facilitate processes of mutual learning from best practices on how to achieve compliance (Hobolth and Sindbjerg Martinsen 2013; Yesilkagit 2011; Scholten 2017).

The ways in which power, capacity, and politicization affect noncompliance at the two levels and stages of the compliance game are summarized in table 2.1.

\section{Expectations}

Conceptualizing compliance as a two-stage game played by rational actors across two levels implies that the more successful member states are in shaping EU policies, the fewer problems they are likely to face in taking these policies. The question is whether the shaping ability and the taking ability of states depend on the same factors. The PCP model suggests that good shapers are also good takers. Effective shapers face lower compliance costs. If they have the capacity to shape the costs, they can also use their capacity to take costs. Even if states are powerful, they do not need to invoke their power to resist compliance and deter enforcement authorities. Politicization, finally, enhances the ability of a state to shape EU law, thereby reducing the importance of the capacity to take it as well as the power to defy compliance. 


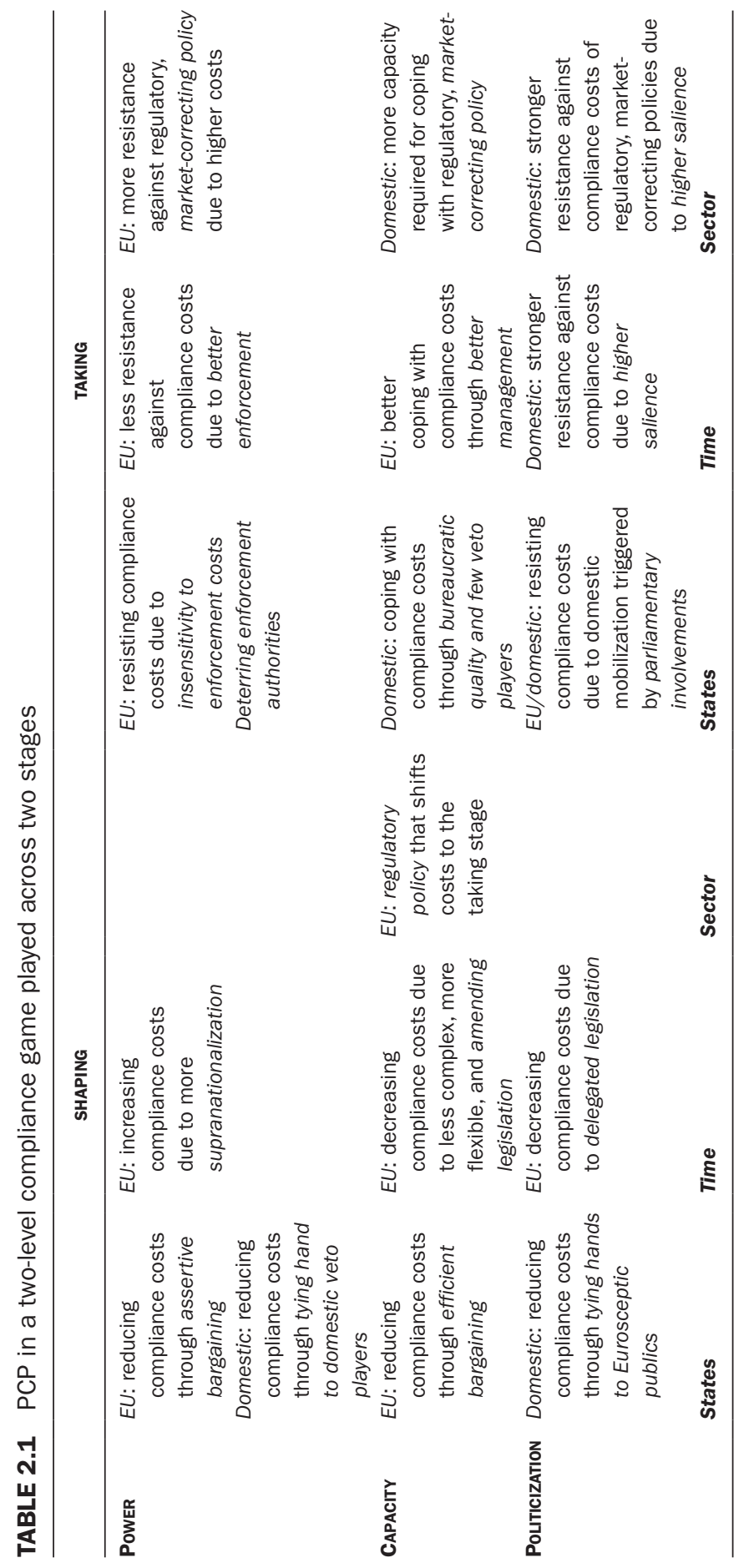


EU-level factors, such as the decision-making rules, the nature of EU laws, and the enforcement and management capacity of EU institutions, should reduce compliance costs for all member states, help them cope with the costs, or influence their propensity of becoming politicized. Rather than explaining country variation, EU institutions help account for changes in noncompliance across time and policy sectors.

Based on these considerations, the PCP model allows us to formulate fairly clear expectations for empirical research regarding the variation in noncompliance across countries, time, and policy sectors. While capacity should have a negative effect on noncompliance at both the shaping and the taking stages, power and politicization pull in opposite directions. Strong power and the propensity of politicization strengthen the ability of states to reduce compliance costs at the shaping stage, making noncompliance less likely. At the same time, however, power allows states to resist compliance costs, while politicization decreases the autonomy of states to take them. Taking into account all the possible combinations would make for a very complex model. Existing research, including my own, has found that power matters more for taking than for shaping, while for politicization it is the other way round (Mbaye 2001; Giuliani 2003; Sverdrup 2004; Perkins and Neumayer 2007; Jensen 2007; Börzel et al. 2010). I will therefore consider politicization only at the shaping stage and power only at the taking stage. Power and politicization are expected to have adverse effects on noncompliance at the shaping and the taking stages. This will allow me to empirically test whether my intuition is correct.

(1) Powerful states with weak capacity and low levels of politicization show more noncompliance than less powerful member states with strong capacity and a high propensity of politicization.

Powerful states with weak capacity and low levels of politicization may be able to push through their preferred policy outcomes at the EU level. At the same time, even their power is mitigated by QMV, and their bureaucracies are not efficient enough to shape EU laws otherwise. Nor can they tie their hands to domestic opposition against costly EU laws. Their low capacity, as well as their power to resist compliance costs and to deter enforcement authorities, turns them into poor takers of EU law. Less powerful states, in contrast, are not able to force their preferences on other member states. With their capacity, however, they can still be effective shapers of EU law, particularly if EU law is likely to become politicized. Their strong capacity, on the one hand, and their lack of power to defy compliance and deter enforcement authorities, on the other, make them effective takers of costly EU laws.

In sum, a decline in power and a growth in capacity decrease the chances of noncompliance. At a given level of power and capacity, politicization brings 
noncompliance down, since it lowers the relevance of power to resist compliance and deter enforcement authorities, as well as the need for capacity to ensure effective implementation. Put differently, politicization reduces the positive effect of power and enhances the negative effect of capacity on noncompliance. Once the empirical analysis of chapter 3 shows whether my intuition is correct, I will model the eight different outcomes of the combination of power, capacity, and politicization, placing them on a continuum between high and low noncompliance.

The PCP model conceptualizes power, capacity, and politicization as countryrelated factors, which are rather time and policy invariant. EU institutions mitigate the effect of these three factors on noncompliance and thereby allow us to account for variation across time and policy.

(2) The more institutions constrain the shaping power of states, make resistance to compliance more costly for them, spare or strengthen their capacity to cope with compliance costs, and lower the chances of compliance costs becoming politicized, the less likely noncompliance becomes.

Supranational decision-making rules deprive member states of their power to veto costly EU laws. EU institutions thereby make noncompliance more likely by increasing costs. Their more effective monitoring and sanctioning render noncompliance more costly. At the same time, EU capacity building helps member states to cope with compliance costs. Differentiated integration eases compliance costs by allowing member states to opt out of legal obligations (temporarily). EU laws that introduce new and complex regulations are more demanding on member state capacities and more prone to noncompliance. Delegated legislation entails not only less costs because of its technicality. Owing to the lack of parliamentary involvement, these costs are less likely to become politicized at the domestic level.

(3) Policy sectors that impose higher costs, being more likely to be politicized, attract more noncompliance than policy sectors that are less demanding on state capacity and are politically less sensitive.

Policies systematically differ with regard to the compliance costs they incur on states. Regulatory policy entails higher compliance costs than nonregulatory policy, particularly if the aim is to harmonize social, political, or environmental standards of the member states to protect EU citizens against market failure. Replacing national regulation by new EU regulation requires not only capacity to cope with the costs. These costs are also more likely to be politicized.

The empirical analyses in chapters 3-5 evaluate these theoretical expectations. They also control for social constructivist factors that may influence how 
governments shape and take EU law, affecting their chances of noncompliance. Socialization and legitimacy give rise to expectations that conflict with the PCP.

(4) The more states are socialized into EU law, the less noncompliant they are.

Member states are socialized into EU law, internalize its supremacy, and take it for granted. This should privilege the "upgrading of the common interest" (E. Haas 1958, 287) over the pursuit of purely national self-interest in the shaping of EU law, which is likely to result in EU laws that are costly for all member states. Member states should also have a default preference for compliance, irrespective of the compliance costs incurred.

(5) The less legitimacy the EU and EU law enjoy, the more likely is noncompliance.

A rule is legitimate because it is embedded in an underlying institution or a legal system that is generally characterized by a high level of social acceptance (Hurd 1999; Kohler-Koch 2000). Voluntary compliance is generated by the diffuse support for and the general acceptance of the rule-setting institution. Rules are not only complied with because laws ought to be obeyed, but because the rules are set by institutions that enjoy a high degree of support and general acceptance (Dworkin 1986; Hurrell 1995; Gibson and Caldeira 1995; Hurd 1999; Franck 1990; Finnemore and Toope 2001; Checkel 2001). The social constructivist expectation is the opposite of what the PCP model suggests. Low public support for the EU means a higher propensity of politicization, resulting in less rather than more noncompliance at a given level of power and capacity.

Beside institutional legitimacy, actors comply even with costly rules because they believe that these rules have been adopted "in accordance with right process" (Franck 1990, 706). This procedural legitimacy can be generated by involving the same actors in the shaping of EU law at the EU level who are in charge of taking EU law at the domestic level. They will then effectively implement decision outcomes and comply with them, regardless of the costs and benefits involved, because they perceive the decision-making process as right and fair (Dworkin 1986; Hurrell 1995).

The PCP model developed in this chapter lends itself to more than three propositions. Likewise, social constructivist research on compliance offers more than two alternative or competing hypotheses. However, the five hypotheses speak directly to the three puzzles the remainder of the book explores: why old member states comply less than new member states, why noncompliance has declined since the 1990s, and why noncompliance is most prevalent in areas of EU law that protect citizen rights. 
The PCP model focuses on variation in noncompliance of states. Since the governments of the member states dominate both stages of the compliance game, linking the two, their ability to shape and take compliance costs of EU law plays a prominent role. Powerful member states with strong capacity and a high propensity of politicization should be both effective shapers and takers and hence show lower levels of noncompliance. Conversely, member states with limited power, capacity, and politicization are unlikely to effectively shape or take EU law and should be among the top noncompliers.

EU institutions affect power, capacity, and politicization. As systemic factors, EU institutions allow us to account for variation in noncompliance across time and policy sectors. The extension of supranational rules and procedures mitigates the power of member states to reduce compliance costs. The strengthening of EU monitoring and sanctioning mechanisms renders resistance against compliance more costly, while increased EU capacity building helps member states cope with compliance costs. Certain types of EU law, finally, require less capacity and have a lower propensity to become politicized at the domestic level.

Chapters 3-5 apply the PCP model to each of the three puzzles the book seeks to tackle. To explain why long-standing member states are less compliant than new member states, why overall noncompliance has declined since the 1990s, and why noncompliance is more pronounced in sectors of EU law that protects citizen rights, I proceed in three steps. First, I review the existing literature for conceptualizations and operationalizations of power, capacity, and politicization and analyze their empirical relevance. In the second step, I employ my findings to specify the PCP model. This will prevent inflating the model with too many variables. Finally, I evaluate the empirical implications of the PCP model by using descriptive data, statistical data, and narrative evidence. The concluding chapter of this book reassembles the model in light of the empirical findings of chapters $3-5$, presenting a comprehensive theoretical account of noncompliance in the $\mathrm{EU}$ and beyond. 